\title{
Skład, kwalifikacje i liczebność poselstw uczestniczących w kongresie westfalskim
}

\begin{abstract}
Zarys treści: W kongresie westfalskim (1643-1648) wzięły udział 194 oficjalne przedstawicielstwa dyplomatyczne, z czego 178 pochodziło z Rzeszy Niemieckiej, a pozostałe z 16 innych państw europejskich. Uczestnicy rokowań pokojowych odznaczali się wysokim profesjonalizmem i posiadali często wykształcenie prawnicze (nawet doktoraty i profesury). Największe doświadczenie w prowadzeniu negocjacji mieli reprezentanci państw europejskich, wśród których można było spotkać osoby zatrudnione w służbie dyplomatycznej od ponad 20 lat.

Abstract: There were 194 official delegations participating in the Congress of Westphalia (1643-1648), 178 of which came from the German Reich, while the remaining 16 from other European states. The participants of the peace negotiations were highly professional and often were well educated lawyers (even doctors and professors of law). The most experienced negotiators were the representatives of European states, among whom there were persons who had been employed in diplomatic service for more than 20 years.
\end{abstract}

Słowa kluczowe: historia dyplomacji, traktaty międzynarodowe, pokój westfalski, kadry dyplomatyczne państw europejskich

Keywords: history of diplomacy, international treaties, Peace of Westphalia, diplomatic service of European countries

Na temat kończących wojnę trzydziestoletnią (1618-1648) rokowań westfalskich i biorących w nich udział dyplomatów napisano już sporo książek i artykułów. Świadczy o tym najlepiej licząca 475 stron bibliografia dotycząca tej tematyki wydana w 1996 r. pod redakcją Heinza Duchhardta ${ }^{1}$. Do tego wykazu należałoby dodać jeszcze setki nowych dzieł powstałych do 2019 r. Mimo takiego bogactwa opracowań słabo rozpoznane pozostają wciąż kwalifikacje wielu uczestników negocjacji pokojowych. Niedużo wiemy na temat ich wykształcenia, pochodzenia oraz przebiegu kariery. Informacje na ten temat pozostają w dużym rozproszeniu. Zajmowano się bowiem przede wszystkim najpoważniejszymi graczami politycznymi, pomijając milczeniem bądź zaledwie sygnalizując przedstawicieli mniej ważnych i mniej aktywnych państw europejskich oraz niemieckich władztw terytorialnych. Brakuje wciąż prac charakteryzujących kadrę dyplomatyczną obecną na kongresie westfalskim w ujęciu

${ }^{1}$ Bibliographie zum Westfälischen Frieden, red. H. Duchhardt, Münster 1996 (Schriftenreihe der Vereinigung zur Erforschung der Neueren Geschichte 26). 
kompleksowym. Trudno uznać za taką obszerną, ale poświęconą wyłącznie delegacji francuskiej monografię pióra Anuschki Tischer ${ }^{2}$ czy też artykuły dotyczące działalności wybranych poselstw, zawarte w zbiorze studiów opublikowanym w 1998 r. ${ }^{3}$ Zdecydowanie lepiej prezentują się na tym tle badania nad liczebnością towarzyszącego dyplomatom personelu oraz finansowania poszczególnych delegacji. Doczekaliśmy się na ten temat całościowego i wyczerpującego omówienia ${ }^{4}$.

Celem niniejszego artykułu jest przyjrzenie się osobom uczestniczącym w zawarciu jednego z najbardziej znaczących traktatów międzynarodowych w historii nowożytnej Europy w skali ogólnej. Nie będzie to możliwe bez prezentacji - na tyle, na ile pozwalają na to dostępne źródła i literatura - zdobytych przez dyplomatów umiejętności i kompetencji. Obserwacja zbiorowości negocjatorów z innej niż dotąd perspektywy umożliwi znalezienie odpowiedzi na pytanie, czy wszystkie państwa europejskie i niemieckie władztwa terytorialne przygotowały się do konferencji pokojowej z należytą starannością. Pozwoli również na ocenę stanu europejskiej dyplomacji i jej aparatu organizacyjnego oraz wskazanie najsłabszych ogniw. Realizując przyjęte kryteria, zajmę się między innymi ignorowaną dotąd delegacją polską na rokowania westfalskie. W opracowaniu dziejów dyplomacji polskiej poświęcono jej zaledwie trzy zdania, wymieniając przy okazji nazwisko tylko jednego z dwóch wysłanników ${ }^{5}$.

Analizę misji dyplomatycznych utrudnia bez wątpienia fakt, że w kongresie westfalskim brały udział aż 194 oficjalne podmioty polityczne, z czego 178 pochodziło z Rzeszy Niemieckiej. Największą grupę stanowili przedstawiciele stanów Rzeszy (Reichsstände), wśród których znajdowało się 8 członków kolegium elektorskiego, 75 książąt duchownych i świeckich oraz 57 miast Rzeszy (Reichstädte). Do tego dochodziło jeszcze 38 innych bytów politycznych, które nie istniały w żadnej z trzech kurii sejmujących stanów. Wymienić tutaj można opatki, opatów, prałatów cesarskich (Reichsprälaten), rycerzy cesarskich (Reichsritterschaft), miasta krajowe podlegające władcom terytorialnym (Mediatstädte), jak np. Osnabrück i Minden, a także pojedyncze osoby pochodzenia arystokratycznego, zainteresowane wynikiem obrad. W tej ostatniej kategorii mieścił się hrabia Lodewijk von Egmond, pretendent do księstwa geldryjskiego, reprezentowany na kongresie westfalskim przez Pellegrino Carleniego opata z włoskiego Lugnano in Taverina. Oprócz niego stawił się jeszcze pełnomocnik Ernesta Bogusława księcia Croy i Aerschot, wnuka księcia pomorskiego Bogusława XIII (Balthasar Magnus von Wedel). Jednego plenipotenta posiadali na kongresie także rycerze cesarscy z Frankonii i Szwabii. Był nim Wolfgang von Gemmingen ${ }^{6}$. W imieniu kilkudziesięciu opactw (m.in. benedyktynów

${ }^{2}$ A. T is cher, Französische Diplomatie und Diplomaten auf dem Westfälischen Friedenskongress. Außenpolitik unter Richelieu und Mazarin, Münster 1999.

${ }^{3}$ Der Westfälische Friede. Diplomatie - politische Zäsur - kulturelles Umfeld Rezeptionsgeschichte, red. H. Duchhardt, München 1998.

${ }^{4}$ F. B o s b a c h, Die Kosten des Westfälischen Friedenskongresses. Eine strukturgeschichtliche Untersuchung, Münster 1984.

${ }^{5} \mathrm{H}$. W i s n e r, Dyplomacja polska w latach 1572-1648, w: Historia dyplomacji polskiej, t. II, Warszawa 1982, s. 92.

${ }^{6}$ Acta Pacis Westphalicae (dalej cyt.: APW), seria III, dział D: Varia, t. I: Stadtmünsterische Akten und Vermischtes, opr. H. Lahrkamp, Münster 1964, s. 345-354; F. B o s b a c h, Die Kosten, s. 14-16, 248, 250. Zob. także R. E n d r e s, Die Friedensziele der Ritterschaft, w: Der 
z klasztoru św. Emmerama w Ratyzbonie i Kornelimünster w Akwizgranie) oraz prałatów cesarskich z okręgu szwabskiego występował w Westfalii doktor teologii, przeor benedyktyńskiego opactwa św. Januarego w Murrhardt Adam Adami. Był on ponadto delegatem księcia-opata Corvey Arnolda von Waldois i wspólnie z biskupem Osnabrück, hrabią Franciszkiem Wilhelmem von Wartenberg, oraz Johannem von Leuchselring kierował na kongresie partią katolickich maksymalistów. Sprzeciwiał się ugodowej polityce cesarza i jego głównego przedstawiciela dyplomatycznego, hrabiego Maximiliana von Trauttmansdorff. Głosił poglądy radykalne, uważając między innymi, że kończąca się wojna była karą boską dla imperium za „grzeszne” tolerowanie herezji. Zaangażowanie Adamiego w obronę stanu posiadania Kościoła katolickiego w Szwabii nie zostało jednak uwieńczone sukcesem7

Opatki i opaci powierzali reprezentowanie swoich interesów także innym wpływowym osobom. Zwierzchnik opactwa benedyktyńskiego św. Maksymina w Trewirze przekazał swój głos delegatowi Burgundii Peterowi von Weyms, opatka klasztoru benedyktynek w Andlau - delegatowi Zakonu Krzyżackiego Johannowi von Giffen, księżna-opatka z Lindau Anna Krystiana Hundbiss von Waltrams - delegatowi Augsburga, doktorowi nauk prawnych Johannowi von Leuchselring, a księżna-opatka z Buchau Katarzyna von Spaur - posłowi biskupa Konstancji, doktorowi nauk prawnych Johannowi Georgowi Köberlinowi. Wyłom w tej praktyce uczyniła księżna-opatka z Essen Anna Salome von Salm-Reifferscheidt, która wysłała na kongres własnego delegata, licencjata prawa Bernharda Tripodiusa ${ }^{8}$.

Hierarchowie kościelni brali często przykład z opatów i opatek, cedując swoje głosy na delegatów innych duchownych władztw terytorialnych. Największym zaufaniem wśród nich cieszył się biskup Osnabrück, hrabia von Wartenberg, reprezentujący arcybiskupstwo i elektorat Kolonii, biskupstwo Augsburga, Chur, Eichstätt, Hildesheim, Liège (niem. Lüttich), Minden, Münster, Paderborn, Verden i Ratyzbony oraz księstwo-prepozyturę (Fürstpropstei) Berchtesgaden. Większość świeckich władców terytorialnych polegała na własnych dyplomatach, wystawiając najczęściej jednego bądź dwóch przedstawicieli. Przykładowo interesy książąt brunszwicko-lüneburskich z Grubenhagen i Calenberg reprezentował Jakob Lampadius, margrabiego badeńskiego na Durlach Fryderyka V - radca Johann Georg von Merkelbach, elektora Bawarii Maksymiliana I - marszałek dworu, baron Georg Christoph von Haslang i doktor nauk prawnych Johann Adolf Krebs, a elektora Saksonii Jana Jerzego I - radca nadworny Johann Ernst Pistoris i doktor nauk prawnych Johann Leuber ${ }^{9}$. Najwybitniejszą postacią w tym gronie był bez wątpienia Jakob Lampadius, profesor prawa na uniwersytecie w Helmstedt, a następnie wicekanclerz książąt brunszwicko-lüneburskich Jerzego i Chrystiana Ludwika. Uzyskał on szybko na kongresie westfalskim rolę rzecznika protestanckich stanów. Przyczynił się do uznania kalwinizmu trzecim,

Westfälische Friede (jak w przyp. 3), s. 565-578; H. N e u h a u s, Das Reich in der frühen Neuzeit, München 1997 (Enzyklöpedie deutsche Geschichte 42), s. 34-36.

${ }^{7}$ APW, seria III, dział D: Varia, t. I, s. 352-353; P. Vo 1 k, Adami Adam, w: Neue deutsche Biographie, t. I (1953), s. 55-56; P. H. W i 1 s o n, Wojna trzydziestoletnia 1618-1648. Tragedia Europy, tłum. M. Kapałczyński, Oświęcim 2017, s. 692-693.

${ }^{8}$ APW, seria III, dział D: Varia, t. I, s. 353.

9 Tamże, s. 348-350. 
obok katolicyzmu i luteranizmu, legalnym wyznaniem w Rzeszy. Podejmował także inicjatywy zmierzające do zapewnienia każdemu, nawet najprostszemu, Niemcowi wolności sumienia ${ }^{10}$.

Delegacje miast niemieckich nie odbiegały pod względem liczebności od poselstw większości świeckich władców terytorialnych. Po jednym przedstawicielu miały na kongresie westfalskim takie miasta, jak: Magdeburg (słynny niemiecki fizyk i fortyfikator, burmistrz Otto von Guericke), Hamburg (syndyk, doktor nauk prawnych Johann Christoph Meurer), Lubeka (syndyk, doktor nauk prawnych David Gloxin) czy Dortmund (syndyk Georg Kumpsthoff). Dwuosobowe reprezentacje złożone z urzędników miejskich posiadało 12 miast, między innymi Akwizgran (burmistrz, doktor nauk prawnych Joachim Berchem i syndyk, licencjat prawa Rudolf Twist), Osnabrück (doktorzy nauk prawnych: burmistrz Gerhard Schepeler i syndyk Johann Heinrich Böger) i Erfurt (burmistrz Johann Hallenhorst i syndyk Rudolf Geisler). Znamienne, że na wystawienie trzyosobowych przedstawicielstw zdecydowały się tylko dwa miasta: Brema (syndyk, doktor nauk prawnych Gerhard Koch, członek rady miejskiej Bremy Liborius von Linen i doktor nauk prawnych Johann Wachmann) i Kolonia (burmistrz Konstantin von Lyskirchen, syndyk Gerwin Meinertshagen i doktor nauk prawnych Hermann Halveren). Wśród delegatów miejskich trafiali się także urzędnicy cesarscy. Delegacji Besançon, stolicy hrabstwa Burgundii, przewodził cesarski radca, doktor nauk prawnych Franz Paul von Lisola, znany Polakom z mediacji przy zawieraniu w 1657 r. traktatów welawsko-bydgoskich z elektorem brandenburskim Fryderykiem Wilhelmem. Lisola przybył na dwór cesarski w 1639 r. i dzięki protekcji hrabiego Maximiliana von Trauttmansdorff rozpoczął szybko służbę dyplomatyczną. W latach 1640-1645 posłował do Anglii i Niderlandów Hiszpańskich, starając się tam intrygować przeciw Francji. Jego rola w Münster ograniczała się do wspomagania dyplomacji habsburskiej ${ }^{11}$. Świetnie obeznani z prawem delegaci miejscy bronili niejednokrotnie spraw więcej niż jednego zleceniodawcy. Przykładowo wysłannik Strasburga, doktor nauk prawnych Markus Otto, posiadał również uprawnienia do reprezentowania interesów trzech innych miast - Spiry, Landau i alzackiego Weißenburga oraz hrabiego Jana Kazimierza von Salm-Kyburg. Podobnie rzecz się miała z przedstawicielem Lubeki, Davidem Gloxinem, występującym na kongresie w imieniu miast Goslar i Nordhausen oraz Augusta księcia saskiego na Lauenburgu, czy posłem Frankfurtu nad Menem, syndykiem i doktorem nauk prawnych Zachariasem Stenglinem, sprawującym mandat w imieniu Wormacji i hrabiów Oettingen. Rekordzistą w tej dziedzinie był wspomniany już jurysta Johann von Leuchselring, delegat Augsburga i tamtejszy kanclerz, sprawujący w Westfalii rolę

${ }^{10}$ R. D i etrich, Jacobus Lampadius. Seine Bedeutung für die deutsche Verfassungsgeschichte und Staatstheorie, w: Forschungen zu Staat und Verfassung. Festgabe für Fritz Hartung, Berlin 1958, s. 163-185; C. S tro h m, Calvinismus und Recht. Weltanschaulich konfessionelle Aspekte im Werk reformierter Juristen in der Frühen Neuzeit, Tübingen 2008, s. 349-364.

11 APW, seria III, dział D: Varia, t. I, s. 353-354; R. P o s te 1, Zur „erhaltung dern commercien und darüber habende privilegia". Hansische Politik auf dem Westfälischen Friedenskongreß, w: Der Westfälische Friede (jak w przyp. 3), s. 523-525; A. F. P r i b r a m, Franz Paul Freiherr von Lisola (1613-1674) und die Politik seiner Zeit, Leipzig 1894, s. 6-57. 
plenipotenta jeszcze piętnastu innych miast, a także księżnej-opatki z Lindau i kilku szwabskich hrabiów ${ }^{12}$.

Na zaprezentowanym tle wyróżniały się poselstwa czterech niemieckich władców terytorialnych. Pięcioosobowe zespoły negocjatorów wyekspediowała do Westfalii wdowa po landgrafie Hesji na Kassel Wilhelmie V, Amelia Elżbieta von Hanau, sprawująca regencję w imieniu małoletniego syna Wilhelma VI (tajni radcy Adolf Wilhelm von Krosigk, Johannes Vultejus i Reinhard Scheffer, doktorzy nauk prawnych Johann Antrecht i Nikolaus Christoph Muldener), arcybiskup-elektor Kolonii Ferdynand Wittelsbach (biskup Osnabrück, hrabia Franciszek Wilhelm von Wartenberg, prepozyt katedralny z Paderborn Dietrich Adolf von der Recke, kanonik koloński Arnold von Landsberg, kanclerz Münster Dietrich Hermann von Merveldt i kanclerz Paderborn, tajny radca koloński, doktor nauk prawnych Peter Buschmann) i elektor brandenburski Fryderyk Wilhelm (hrabia Johann von Sayn-Wittgenstein, tajny radca, baron Johann Friedrich von Löben, radca kameralny Matthäus Wesenbeck, Friedrich von Heiden i doktor nauk prawnych Johann Fromhold). Rekordową, sześcioosobową grupą dyplomatów mógł poszczycić się arcybiskup-elektor Moguncji Anzelm Kazimierz Wambolt von Umstadt i jego następca na tronie arcybiskupim, Jan Filip von Schönborn (radca elektorski Hugo Eberhard Cratz von Scharfenstein, kanclerz moguncki Nikolaus Georg Raigersberger, baron Heinrich Brömser von Rüdersheim i trzej prawnicy, doktorzy Johann Adam Krebs, Peter Braem, Sebastian Wilhelm Meel) ${ }^{13}$.

Nadzwyczajną liczebność wyżej wymienionych poselstw można wytłumaczyć wzmożoną aktywnością dyplomatyczną niektórych terytorialnych władców niemieckich. Zabiegali oni o zwrot okupowanych przez obce wojska ziem bądź domagali się stosownych rekompensat za odstępowane mocarstwom terytoria. Starania te przyniosły im - jak się później okazało - wymierne korzyści. Arcybiskup moguncki Schönborn połączył w swym ręku Moguncję z biskupstwem w Würzburgu, a arcybiskup koloński Ferdynand Wittelsbach zapewnił sobie władzę w kilku diecezjach i poza Kolonią rządził jeszcze w Liège, Münster, Hildesheim i Paderborn. Ponadto wynagrodzono sowicie najwierniejszych niemieckich sojuszników Szwecji i Francji landgrafów Hesji na Kassel. Regentka Amelia Elżbieta von Hanau otrzymała bowiem w artykule XV pokoju z Osnabrück odszkodowanie w wysokości 600000 talarów oraz nabytki terytorialne - opactwo Hersfeld i część dawnego hrabstwa Schaumburg. Potwierdzono także porozumienie zawarte 14 IV 1648 r. między władcami heskimi z Kassel i Darmstadt, które przewidywało przekazanie regentce i jej synowi okręgu Marburga ${ }^{14}$.

${ }^{12}$ APW, seria III, dział D: Varia, t. I, s. 351-354.

13 Tamże, s. 347-348, 351; P. B a u m g a r t, Kurbrandenburgs Kongreßdiplomatie und ihre Ergebnisse, w: Der Westfälische Friede (jak w przyp. 3), s. 473-474; W. H o n s e $1 \mathrm{~m}$ a n n, Peter Buschmann, Kanzler in Paderborn und Köln (1604-1673), Westfälische Zeitschrift 120, 1970, s. 392-396.

${ }^{14}$ APW, seria III, dział B: Verhandlungsakten, t. I: Die Friedensverträge mit Frankreich und Schweden, cz. 1: Urkunden, opr. A. Oschmann, Münster 1998, s. 144, 146-150; K. E. D e m a ndt, Geschichte des Landes Hessen, Kassel 1959, s. 197-199; L. E n n e n, Ferdinand Erzbischof und Kurfürst von Köln, w: Allgemeine deutsche Biographie (dalej cyt.: ADB), t. VI, Leipzig 1877, s. 691-697. 
Największym beneficjentem pokoju westfalskiego został elektor brandenburski Fryderyk Wilhelm. Nie otrzymał on odszkodowania w postaci części habsburskiego Śląska, o którą zabiegał, ale i tak powiększył terytorium swojej monarchii niemal o jedną trzecią przez przyłączenie wschodniej części Pomorza, tzw. Pomorza Tylnego (Hinterpommern), oraz zsekularyzowanych biskupstw Kamienia, Minden i Halberstadt. Hohenzollern otrzymał także arcybiskupstwo magdeburskie, które miał jednak przejąć dopiero po śmierci aktualnego administratora, księcia saskiego Augusta. W rezultacie Magdeburg dostał się w ręce Hohenzollerna w 1680 r. ${ }^{15}$

O rozmaite korzyści biły się na kongresie westfalskim nie tylko byty polityczne pochodzące z Rzeszy Niemieckiej. W gronie uczestników rokowań znalazło się bowiem jeszcze 16 państw europejskich: Stolica Apostolska, Wenecja, Królestwo Danii i Norwegii, Francja, Szwecja, Hiszpania, Portugalia, Republika Zjednoczonych Prowincji Niderlandzkich, Genua, Mantua, Sabaudia, Wielkie Księstwo Toskanii, Katalonia, Rzeczpospolita Obojga Narodów i Siedmiogród. Wydawcy monumentalnej edycji źródłowej Acta Pacis Westphalicae, a w ślad za nimi Franz Bosbach zaliczyli do tego gremium także cesarza, pominęli zaś Szwajcarię reprezentowaną na kongresie przez burmistrza Bazylei Johanna Rudolfa Wettsteina. Szwajcaria uniezależniła się od Rzeszy na mocy pokoju zawartego 22 IX 1499 r. w Bazylei. Jednak sama Bazylea, podobnie jak Szafuza, dołączyła do Konfederacji Szwajcarskiej dopiero w $1501 \mathrm{r}$. i była traktowana inaczej niż najstarsi członkowie związku. Stąd też uważano Wettsteina za osobę pochodzącą z Rzeszy Niemieckiej ${ }^{16}$. Burmistrz Bazylei nie mógł pochwalić się znakomitym wykształceniem. Posiadał jednak bogate doświadczenie prawnicze, administracyjne i wojskowe. Po ukończeniu szkoły średniej (Schule auf Burg) w Bazylei pracował w kancelariach prawnych w Yverdon i Genewie (1608-1610), później zaś od 1616 r. służył wojskowo jako najemnik we Włoszech. Powróciwszy do Bazylei, został w 1620 r. członkiem rady miejskiej. Był również landwójtem w Farnsburgu (1624-1626) i nadwójtem w Riehen pod Bazyleą (1626-1635) ${ }^{17}$.

Na pierwszy rzut oka można stwierdzić, że w Westfalii pojawili się dyplomaci z wszystkich państw europejskich z wyjątkiem Anglii, Rosji, Turcji i Księstwa Modeny. Ich udział w pertraktacjach nie był jednak taki sam. Uczestnictwo Siedmiogrodu w kongresie westfalskim było zaledwie epizodyczne. Poseł księcia siedmiogrodzkiego Jerzego I Rakoczego, Ferenc Jármi, wykorzystywany wcześniej do kontaktów z Radziwiłłami, przebywał w Münster tylko przejazdem od $25 \mathrm{~V}$ do 14 VI 1646 r. Prawdziwym celem jego legacji był Paryż. Książę Siedmiogrodu nie widział potrzeby angażowania się w prowadzone w Westfalii negocjacje, choć jeszcze

15 APW, seria III, dział B, t. I, cz. 1, s. 136-141; P. B a u m g a r t, Kurbrandenburgs, s. 472-473, 476-483; B. W a c h ow i a krzy współudziale A. K a m i eń s k i e g o, Dzieje Brandenburgii-Prus u progu czasów nowożytnych (1500-1701), Poznań 2001, s. 347-352.

${ }_{16}$ APW, seria III, dział D: Varia, t. I, s. 345-347, 353; F. B o s b a c h, Die Kosten, s. 14-15, 20, 226-227; T. B r a n e c k i, Powstanie i rozwój Konfederacji Szwajcarskiej w latach 12911515, Studia Iuridica Lublinensia 19, 2013, s. 95-96; F. G a 11 a ti, Die formelle Exemtion der Schweiz vom Deutschen Reich im Westfälischen Frieden, Zeitschrift für Schweizerische Geschichte 28, 1948, s. 461-473.

17 F. F ä h, Wettstein Johann Rudolf, w: ADB XLII (1897), s. 240-242; J. G a u s s, A. S t o e c k 1 i n, Bürgermeister Wettstein. Der Mann, das Werk, die Zeit, Basel 1953, s. 17-24. 
niedawno najeżdżał ziemie Habsburgów w sojuszu z Francją i Szwecją. Rakoczy 16 XII 1645 r. podpisał w Linzu pokój z Austrią i wycofał się definitywnie z wojny na korzystnych dla siebie warunkach ${ }^{18}$. Drugoplanowa rola przypadła przedstawicielom czterech państw włoskich: Republiki Genui (Niccolo Promontorio) ${ }^{19}$, Księstwa Mantui (najwyższy prezes sądu mantuańskiego Francesco Nerli hrabia Valdery i szlachcic z Casale Monferrato, hrabia Girolamo Sannazaro), Księstwa Sabaudii (były ambasador Sabaudii we Francji Claude Jêrome Chabod markiz di Saint-Maurice, przewodniczący senatu piemonckiego, doktor nauk prawnych Giovanni Francesco Bellezia i doktor nauk prawnych, potem profesor na uniwersytecie w Turynie, członek senatu piemonckiego Lorenzo Nomis) oraz Wielkiego Księstwa Toskanii (doświadczony dyplomata, piastujący od $1641 \mathrm{r}$. funkcję ambasadora toskańskiego w Wiedniu, Atanasio Ridolfi). Najsilniejszy skład spośród tych państw wystawiła Sabaudia. Wysiłki doświadczonych polityków, dyplomatów i jurystów sabaudzkich zdały się jednak na nic z powodu działań obcych potencji. Pokój między cesarzem a Francją zawarty w Münster nie przyniósł księciu sabaudzkiemu Karolowi Emanuelowi II żadnych korzyści. Nie uzyskał statusu elektoratu i musiał pogodzić się z usankcjonowaniem ekspansji Francji na terenie północnych Włoch. Postanowienia westfalskie potwierdziły bowiem traktat pokojowy z Cherasco zawarty 6 IV 1631 r., a co za tym idzie, prawa przedstawiciela francuskiej linii rodu Gonzagów z Nevers, Karola III, do Księstwa Mantui i Monferrato oraz oderwanie od Sabaudii części Piemontu z miastem Pinerolo ${ }^{20}$.

Jeszcze słabiej niż wyżej wymienione państwa włoskie zaznaczyli swoją obecność wysłannicy polskiego władcy. Stało się tak na wyraźne życzenie elit politycznych Rzeczypospolitej Obojga Narodów, które skupiły się na śledzeniu postępu rokowań, zwłaszcza w kwestiach dotyczących Szwecji. Interesy polskie w Westfalii reprezentował w latach 1643-1644 wynajęty pełnomocnik Heinrich Christoph von Griesheim. Pochodził on z hrabstwa Schwarzburg, ze wschodniej części dzisiejszej Turyngii, i zasłynął wcześniej głównie z ustawicznego zmieniania protektorów i miejsc pracy. Już w wieku dwudziestu kilku lat związał się z hrabią Ernestem von Holstein-Schaumburg. W 1621 r. został profesorem prawa w założonym przez hrabiego uniwersytecie w Rinteln, skąd w 1625 r. przeszedł na profesurę do Marburga. Wkrótce potem zrezygnował z kariery naukowej. Dokonał konwersji na

${ }^{18}$ APW, seria III, dział D: Varia, t. I, s. 347; G. Ká r m á n, I. Rákóczi György korai kapcsolatai a Radziwiłł családdal, Acta Academiae Agriensis, Sectio Historiae 44, 2017, s. 64, 70; K. M. S e t t o n, Venice, Austria, and the Turks in the Seventeenth Century, Philadelphia 1991, s. 80-82.

19 Według niemieckich wydawców wywodzący się z genueńskiego patrycjatu Promontorio miał reprezentować Genuę na kongresie westfalskim w latach 1645-1647 (APW, seria III, dział D: Varia, t. I, s. 347). Diametralnie inne informacje podaje V. V i t a le, Diplomatici e consoli della Repubblica di Genova, Atti della Società Ligure di Storia Patria 63, 1934, s. 118, według którego Promontorio miał przybyć do Münster dopiero 27 II 1647, a wyjechał stamtąd do Francji 20 VIII 1649 r.

${ }^{20}$ APW, seria III, dział B, t. I, cz. 1, s. 22, 27-28; seria III, dział D: Varia, t. I, s. 347; V. Castronovo, Bellezia Giovanni Francesco, w: Dizionario Biografico degli Italiani, t. VII, Roma 1965, s. 634-637; A. M e r 1 o t t i, Saint-Maurice, Claude Jêrome Chabod marchese di, w: tamże, t. LXXXIX, Roma 2017, s. 625-627. 
katolicyzm i został tajnym radcą w Düsseldorfie. Nie zagrzał tam długo miejsca. Zerwał związki z księciem Wolfgangiem Wilhelmem von Pfalz-Neuburg i wstąpił do służby u arcybiskupa-elektora Moguncji, którym był wówczas Anzelm Kazimierz Wambolt von Umstadt ${ }^{21}$. Dalsze informacje pojawiające się na jego temat w literaturze są sprzeczne. Jedni autorzy utrzymują, że we wrześniu 1631 dostał się w Fritzlar do niewoli heskiej i odzyskał wolność dopiero w 1638 r. Inni podają wszakże, że Griesheim trafił na dwór arcybiskupa-elektora Trewiru Filipa Krzysztofa von Sötern i w grudniu 1631 r. odbył misję dyplomatyczną do Francji ${ }^{22}$. Tę ostatnią informację potwierdzają przekazy źródłowe. Griesheim uczestniczył bowiem w rokowaniach między elektoratem Trewiru i Francją, które zakończyły się zawarciem 9 IV 1632 r. układu o neutralności. Przyczynił się też do podpisania podobnego porozumienia między Trewirem a Szwecją (22 IV 1632) 23 .

Nieznane są okoliczności wstąpienia Griesheima do polskiej służby dyplomatycznej. Nie znamy również instrukcji wydanej mu przez Polaków. Wiemy tylko, że jego przybycie do Münster zostało odnotowane 26 XI 1643 r. przez dyplomatów cesarskich - hrabiego Johanna Ludwiga von Nassau-Hadamar i Isaaka Volmara. Wysłannik Władysława IV Wazy przekazał wówczas hrabiemu Nassau-Hadamar list rekomendacyjny wystawiony przez króla polskiego 6 X $1643 \mathrm{r}^{24}$ Skierował też pismo do arcybiskupa-elektora kolońskiego Ferdynanda Wittelsbacha, poświęcone polityce szwedzkiej państwa polsko-litewskiego i omawiające związaną z nią misję starosty ermeskiego Henryka Denhoffa na dworze duńskim. Griesheim utrzymywał w tym piśmie, że został wysłany do Westfalii po to, aby składać co tydzień raporty królowi polskiemu ${ }^{25}$. W rzeczywistości wypełniał tam jeszcze inne zadania. W ostatnim doniesieniu posłów cesarskich na temat działalności Griesheima na kongresie pokojowym z $30 \mathrm{~V} 1644$ r. czytamy chociażby o złożonej przez niego propozycji dotyczącej zaprowadzenia pokoju partykularnego w Rzeszy Niemieckiej ${ }^{26}$.

Po zwolnieniu Griesheima przez króla polskiego Władysława IV w 1644 r. nikt nie spieszył się z obsadzeniem wakującego stanowiska. Następcą Griesheima został w końcu Matthias von Krockow, świetnie wykształcony prawnik, który przed wstąpieniem na służbę Władysława IV piastował stanowisko radcy dworu i ochmistrza księżnej Elżbiety von Schleswig-Holstein-Sonderburg, żony księcia pomorskiego Bogusława XIV. Wywodził się ze szlachty lęborskiej i był synem Georga starosty

${ }^{21}$ J. F. J u g l e r, Beyträge zur juristischen Biographie oder genauere litterarische und critische Nachrichten von dem Leben und Schriften, t. VI, Leipzig 1780, s. 18-20; [R.] v . L [ i l i e n c r o n ], Griesheim Heinrich Christoph von, w: ADB IX (1879), s. 665.

22 J. F. J u g 1 e r, Beyträge, s. 19; [R.] v. L [ i 1 i e n c r o n ], Griesheim Heinrich Christoph, s. 665. Por. Allgemeine Encyklopädie der Wissenschaften und Künste in alphabetischer Folge, wyd. J. S. Ersch i J. G. Gruber, sekcja 3, cz. 23, Leipzig 1847, s. 191; Ch. v o n S t r a m b e rg, Ehrenbreitstein, Feste und Thal, w: Denkwürdiger und nützlicher rheinischer Antiquarius, welcher die wichtigsten und angenehmsten geographischen, historischen und politischen Merkwürdigkeiten des ganzen Rheinstroms. Mittelrhein: dział II, t. I, Coblenz 1845, s. 313-314.

${ }^{23}$ APW, seria II, dział A: Die kaiserlichen Korrespondenzen, t. I, opr. W. Engels, E. Merla, Münster 1969, s. 140, przyp. 1.

${ }^{24}$ Tamże, s. 136-140.

25 Tamże, s. 141.

${ }^{26}$ Tamże, s. 446-447. 
darłowskiego, dziedzica Osieków Lęborskich, Kurowa, Ulinii i Słuchowa. W 1637 r., po przejściu ziemi lęborsko-bytowskiej pod rządy polskie, został poddanym Władysława IV. Za kandydaturą Krockowa przemawiały dodatkowe atuty. Dzięki nauce w gimnazjum w Gdańsku i długiemu pobytowi w Toruniu i Poznaniu posługiwał się dobrze językiem polskim. Nie była mu obca również dyplomacja. W 1628 posłował na polecenie Bogusława XIV do bawiącego w Meklemburgii wodza cesarskiego Albrechta Wallensteina, a w 1630 r. - do kwatery króla szwedzkiego Gustawa II Adolfa. Po śmierci ostatniego Gryfity w 1637 r. brał udział w legacji do elektora brandenburskiego Jerzego Wilhelma do Kostrzyna nad Odrą z zawiadomieniem o zgonie oraz w kwestiach dotyczących przyszłości Księstwa Pomorskiego. Wkrótce potem przyłączył się do stronnictwa probrandenburskiego i zaczął oddawać dyplomatom elektorskim rozmaite przysługi ${ }^{27}$.

Kredytywa króla polskiego dla jadącego na kongres westfalski Krockowa została wystawiona w Warszawie 14 VI 1646 r. $^{28}$ Nie znamy treści wydanej dla niego instrukcji. Z opublikowanych materiałów źródłowych wynika wszakże jasno, że Krockow miał przeciwdziałać umocnieniu się Szwedów u ujścia Odry. Ponadto w listopadzie 1646 r. wystąpił w Westfalii - w imieniu króla - z pretensjami do części Pomorza ze Słupskiem, Darłowem i Sławnem. Zabiegi te zakończyły się niepowodzeniem. Poseł szwedzki Johan Adler Salvius wykrył bowiem z łatwością, że roszczenia dworu polskiego zostały oparte na falsyfikatach. Autorem podrobionych dokumentów był słynny polski fałszerz Krzysztof Stanisław Janikowski, który mimo złej renomy cieszył się zaufaniem króla Władysława IV i kanclerza wielkiego koronnego Jerzego Ossolińskiego ${ }^{29}$. Kompromitujący finał całej misji nie złamał kariery Krockowa, który znosił się od pierwszych dni swojego pobytu w Westfalii z Brandenburczykami. Jego największym osiągnięciem było wyśledzenie działań szwedzkich podważających prawa elektora brandenburskiego Fryderyka Wilhelma do dziedzictwa po Gryfitach i udostępnienie dyplomatom Hohenzollerna, Matthäusowi Wesenbeckowi i Johannowi Fromholdowi, tajnych informacji w tej sprawie wydobytych z ambasady francuskiej. Praca Krockowa znalazła uznanie w oczach dworu berlińskiego i zadecydowała o dalszych kolejach jego losu. Szlachcic spod Lęborka porzucił służbę polską i przeniósł się do Brandenburgii-Prus, obejmując kilka lat później urząd tajnego radcy elektorskiego ${ }^{30}$.

Z zupełnie innymi celami przybyły do Westfalii delegacje Katalonii i Portugalii. Do utworzenia tych państw doszło w wyniku powstań wznieconych przeciwko rządom hiszpańskim w 1640 r. w Barcelonie i Lizbonie. Stąd też niepodległość Katalonii

${ }^{27}$ APW, seria III, dział D: Varia, t. I, s. 347; H. S a r i n g, Matthias von Krockow, Baltische Studien, Neue Folge 42, 1940, s. 198-201.

${ }^{28}$ APW, seria II, dział A: Die kaiserlichen Korrespondenzen, t. IV, opr. H. Salm, B. Wübbeke-Pflüger, W. Engels, M. Klett, Münster 2001, s. 589.

${ }^{29}$ Urkunden und Actenstücke zur Geschichte des Kurfürsten Friedrich Wilhelm von Brandenburg, t. I, wyd. B. Erdmannsdörffer, Berlin 1864, s. 211-212; J. R u m ińs ki, Janikowski Krzysztof Stanisław, w: Polski słownik biograficzny, t. X, Wrocław 1962-1964, s. 518-519; H. S a r in g, Matthias von Krockow, s. 201-202. Zob. H. W i s n e r, Dyplomacja polska, s. 92, który podaje błędnie, że kompromitujący finał misji Krockowa w Westfalii nastąpił dopiero w $1648 \mathrm{r}$.

${ }^{30}$ Urkunden und Actenstücke, t. I, s. 513; H. S a r i n g, Matthias von Krockow, s. 201-202. 
i Portugalii była wciąż kwestionowana na arenie międzynarodowej. Przeciwnicy króla hiszpańskiego Filipa IV Habsburga wysłali na kongres pokojowy kompetentnych i profesjonalnych delegatów. Na czele poselstwa katalońskiego stanął Josep (José) Fontanella profesor prawa na uniwersytecie w Barcelonie, jeden z przywódców powstania narodowego, sprawujący od 1643 r. funkcję regenta audiencji, katalońskiego trybunału sądowego. Dygnitarz kataloński, przybyły do Münster 17 III 1644 r. wraz ze swym bratem Francescem, doktorem nauk prawnych, wybitnym pisarzem katalońskiego baroku, starał się współdziałać z dyplomatami francuskimi, licząc na ich pomoc w kwestii uznania państwa katalońskiego. Sprzeciwiał się zdecydowanie projektom rozczłonkowania Katalonii. Usiłował również powiązać kwestię katalońską z rokowaniami holendersko-hiszpańskimi i przeciągnąć na swoją stronę Holendrów. Jego energiczne działania nie spodobały się jednak sternikowi francuskiej nawy państwowej, kardynałowi Mazariniemu. Z tego powodu Josep Fontanella został odwołany z Westfalii w grudniu 1644 r. i zastąpiony przez swego brata, Francesca Fontanellę ${ }^{31}$.

Od dyplomacji francuskiej byli uzależnieni także przedstawiciele króla Portugalii Jana IV. W skład tego poselstwa wchodziło czterech dyplomatów. Jeden z nich, doktor nauk prawnych Rodrigo Botelho de Moraes, zmarł przedwcześnie w styczniu 1645 r. w Osnabrück na skutek niskich, zimowych temperatur. Pozostali Portugalczycy odznaczali się wysokim poziomem merytorycznym. Francisco de Andrade Leitão był doktorem (potem profesorem) prawa na uniwersytecie w Coimbrze, ambasadorem Portugalii w Londynie (1641-1642) i Hadze (1642-1644). Wykształcenie prawnicze i doświadczenie dyplomatyczne posiadali także jego koledzy: Luis Pereira de Castro kanonik z Bragi i Coimbry, członek poselstwa portugalskiego do Republiki Zjednoczonych Prowincji Niderlandzkich (1641), a następnie od 1643 r. ambasador Portugalii we Francji, oraz Cristóvão Soares de Abreu, pełniący od 1641 r. obowiązki sekretarza portugalskiej ambasady we Francji. Nie mogli oni jednak zrealizować w Westfalii swych zamierzeń i utwierdzić świeżo zdobytą państwowość, ponieważ naciski Francji na pełnoprawny udział posłów Portugalii i Katalonii w kongresie przez uznanie ich listów uwierzytelniających zostały skutecznie zablokowane przez dwór wiedeński i madrycki. Decydujący cios zadali wysłannicy króla hiszpańskiego Filipa IV, którzy przekonali do swoich racji mediatorów, zwłaszcza nuncjusza papieskiego Fabio Chigiego ${ }^{32}$.

Do funkcji mediatora w rokowaniach pokojowych w Osnabrück pretendował od ich zarania król Danii Chrystian IV. Z tego względu jego przedstawiciel, radca dworu

${ }^{31}$ S. B o a d a s, Grandes diplomáticos en el congreso de Münster: Diego Saavedra y Josep Fontanella, w: Literatura en la Guerra de Treinta Años, Vigo 2012, s. 151-168; J. C o st a, A. Q u in t a n a, E. S e r r a, El viatge a Münster dels germans Josep i Francesc Fontanella per a tractar les paus de Catalunya, w: Polyglotte Romania. Homenatge a Tilbert Dídac Stegmann, t. I, Frankfurt am Main 1991, s. 257-294; F. S á n c h e z - M a r c o s, The Future of Catalonia. A sujet brûlant at the Münster Negotiations, w: Der Westfälische Friede (jak w przyp. 3), s. $273-291$.

32 APW, seria III, dział D: Varia, t. I, s. 346; E. P r e s t a g e, A embaixada do Dr. Francisco de Andrade Leitão à Holanda (1642-1644), Porto 1923; H. S t e i g e r, Der Westfälische Frieden - Grundgesetz für Europa?, w: Der Westfälische Friede (jak w przyp. 3), s. 46-47; P. C a r d i m, „Portuguese Rebels” at Münster. The diplomatic self-fashioning in mid-17th century European politics, w: tamże, s. 292-333. 
Christoph von der Lippe, pojawił się na miejscu obrad już 10 VII 1643 r. W ślad za nim kilka tygodni później przybyli do Osnabrück wysocy dygnitarze duńscy, kanclerz Just Høg, członek Rady Królestwa Gregor Krabbe oraz hamburski dziekan katedralny i doktor nauk prawnych Lorenz Langermann. Duńskie pośrednictwo pokojowe nie trwało jednak zbyt długo z powodu niechęci Szwecji. Obawy szwedzkiego kanclerza Axela Oxenstierny przed nieobiektywnym rozjemcą były uzasadnione. Duńska delegacja miała bowiem zmusić Szwecję do rozpuszczenia jej armii w Niemczech oraz rezygnacji z nabytków terytorialnych nad Bałtykiem, w tym Pomorza. Atak szwedzki na Danię w grudniu 1643 r. wykluczył mediację Chrystiana IV raz na zawsze. Po podpisaniu traktatu pokojowego w Brömsebro (13 VIII 1645) i zakończeniu wojny duńsko-szwedzkiej o arbitrażu Chrystiana IV nie było już mowy ${ }^{33}$.

W tej sytuacji działania rozjemcze podjęli reprezentant Stolicy Apostolskiej Fabio Chigi i poseł Wenecji Alvise Contarini. Większym doświadczeniem spośród nich dysponował Wenecjanin. Przybywając 16 XI 1643 r. do Münster, miał już za sobą 20 lat służby dyplomatycznej. Był wcześniej ambasadorem Wenecji w Niderlandach (1623-1626), Anglii (1626-1628), Francji (1629-1632), przy Stolicy Apostolskiej (1632-1633) i w Turcji (1636-1641) i - co ważne - cieszył się dobrą opinią na dworze francuskim. Podczas pobytu nad Sekwaną odniósł kilka sukcesów dyplomatycznych. Przekonał króla Ludwika XIII do zawarcia sojuszu z Wenecją. Przyczynił się również do poparcia przez Francję szwedzkiej interwencji w wojnie trzydziestoletniej. Kolega Contariniego, Fabio Chigi, był człowiekiem solidnie wykształconym. Po uzyskaniu na uniwersytecie w Sienie stopnia doktora prawa, filozofii i teologii wstąpił w 1626 r. do stanu duchownego. Pracował w Kurii Rzymskiej, pełnił obowiązki referendarza Trybunału Sygnatury Apostolskiej, później zaś inkwizytora Malty (1634-1639). Służbę dyplomatyczną rozpoczął stosunkowo późno. Na pierwszą wysokiej rangi placówkę dyplomatyczną trafił bowiem dopiero w 1639 r., obejmując stanowisko nuncjusza apostolskiego w Kolonii. Jego głównym atutem była więc dobra znajomość spraw niemieckich. Nie została ona jednak w pełni wykorzystana. Niezastąpioną rolę mediatora między protestantami a katolikami odgrywał Contarini. Było to spowodowane stanowiskiem wysłannika Stolicy Apostolskiej, który wzbraniał się przed udziałem $\mathrm{w}$ bezpośrednich pertraktacjach $\mathrm{w}$ imieniu papieża $\mathrm{z}$ ewangelikami. Jego pryncypialna postawa i zdecydowana obrona interesów Kościoła katolickiego na kongresie westfalskim została nagrodzona. W 1655 r. Fabio Chigi zasiadł na tronie papieskim jako Aleksander VII ${ }^{34}$.

${ }^{33}$ APW, seria III, dział D: Varia, t. I, s. 345; M. B r e g n s b o, Denmark and the Westphalian Peace, w: Der Westfälische Friede (jak w przyp. 3), s. 361-367; F. D i ck m a n n, Der Westfälische Frieden, Münster 1972, s. 199; G. L o r e n z, Die dänische Friedensvermittlung beim Westfälischen Friedenskongreß, w: Forschungen und Quellen zur Geschichte des Dreißigjährigen Krieges, Münster 1981, s. 31-61; K. R e p g e n, Dreißigjähriger Krieg und Westfälische Friede. Studien und Quellen, Paderborn-München-Wien 1998, s. 697-698.

${ }^{34}$ S. A n d r e t t a, La diplomazia veneziana e la pace di Vestfalia (1643-1648), Annuario dell' Istituto storico italiano per l'età moderna e contemporanea 23/24, 1971-1972, s. 3-128; G. B e n z o n i, Contarini Alvise, w: Dizionario Biografico degli Italiani, t. XXVIII, Roma 1983, s. 82-91; M. B r a u b a c h, Der Westfälische Friede, Münster 1948, s. 20-21; F. D i c k m a n n, Der Westfälische Frieden, s. 193-194; K. R e p g e n, Dreißigjähriger Krieg, s. 699-719; S. We s t p h a l, Der Westfälische Frieden, München 2015, s. 44- 47, 52; A. Z a n o n D a 1 
Negocjujące strony podjęły decyzję o nieodbywaniu sesji plenarnych i prowadzeniu negocjacji w ramach rozmów dwustronnych. W gestii rozjemców znalazło się pośrednictwo w rokowaniach między Francją a Habsburgami. Ci ostatni bowiem odmówili prowadzenia formalnych rozmów bezpośrednich. Zastosowanie tego manewru miało umożliwić dworowi wiedeńskiemu i Hiszpanii utrzymanie wspólnego frontu wobec interlokutora. Dwór madrycki negocjował bezpośrednio tylko z Holendrami. Pertraktacje habsbursko-francuskie i holendersko-hiszpańskie toczyły się w Münster, rozmowy ze Szwedami zaś toczyły się w Osnabrück. Po dopuszczeniu do kongresu stanów Rzeszy główny ciężar negocjacji przesunął się do tego ostatniego miasta. To właśnie w Osnabrück przystąpiono do rozwiązywania większości zagmatwanych problemów Cesarstwa. Najważniejsi uczestnicy kongresu utrzymywali poselstwa w obu miastach, a ich przedstawiciele spotykali się jeszcze na nieformalnych zjazdach w Lengerich, Ladbergen i innych miejscowościach położonych między Osnabrück i Münster. Organizowanie takich konferencji leżało w interesie Francji i Szwecji, które uzgadniały na nich wspólne stanowisko na dalszą część obrad ${ }^{35}$.

Krótką prezentację najważniejszych graczy politycznych wypada rozpocząć od poselstwa cesarskiego, któremu przewodził wielki ochmistrz dworu Ferdynanda III, hrabia Maximilian von Trauttmansdorff. Był on najzręczniejszym w kwestiach dyplomatycznych przedstawicielem Hofburga i miał już na swoim koncie niejeden sukces. We wrześniu 1619 r. zaaranżował sojusz między cesarzem Ferdynandem II a władcą Bawarii Maksymilianem I. Po klęsce Czechów pod Białą Górą brał udział w pertraktacjach o pokój z Siedmiogrodem, który ostatecznie podpisał w Nikolsburgu (Mikulov) 31 XII 1621 r. Uważano go również za architekta praskiego traktatu pokojowego kończącego pierwszą fazę wojny trzydziestoletniej, zawartego w 1635 r. między cesarzem i elektorem saskim Janem Jerzym I. Wysłannicy dworu wiedeńskiego pojawili się w Münster w końcu lipca 1643, chociaż Trauttmansdorff dotarł tam dopiero w listopadzie 1645 r. ${ }^{36}$ Prowadzeniem rokowań zajmował się tymczasem uzdolniony polityk, hrabia Johann Ludwig von Nassau-Hadamar, którego wspomagali hrabiowie Johann Weikhart von Auersperg i Johann Maximilian von Lamberg, dokooptowani w skład legacji ze względu na zajmowaną pozycję społeczną i umiejętności zdobyte podczas wieloletniej pracy w Cesarskiej Radzie Nadwornej (Reichshofrat) w Wiedniu. Ich współpracownikami nieszlacheckiego pochodzenia byli: cesarski radca nadworny, licencjat prawa Johann Baptist Krane i doktor nauk prawnych Isaak Volmar. Ten ostatni posiadał duże zaufanie cesarza, a także hrabiny Tyrolu Klaudii Medycejskiej, wdowy po arcyksięciu austriackim Leopoldzie V Habsburgu. Volmar, uważany przez kolegów za karierowicza, był dla Habsburgów

B o, Alvise Contarini, mediatore per la Repubblica di Venezia nel congresso di Vestfalia (1643-1648), Lugano 1971, s. 15-95.

${ }^{35}$ G. Te s k e, Verhandlungen zum Westfälischen Frieden außerhalb der Kongreßstädte Münster und Osnabrück, Westfälische Zeitschrift 147, 1997, s. 63-92; P. H. W i 1 s o n, Wojna trzydziestoletnia, s. 649-650.

${ }^{36}$ F. D i ckmann, Der Westfälische Frieden, s. 195; H. von und zu Egloff s te in, Trauttmansdorff Maximilian Graf von, w: ADB XXXVIII (1894), s. 531-536; S. W e s t p h a 1, Der Westfälische Frieden, s. 63. 
niezmiernie wartościowym negocjatorem. Piastował od 1621 r. urząd kanclerza Alzacji i z racji swego wieloletniego doświadczenia administracyjnego najlepiej z wszystkich orientował się w skomplikowanej sytuacji prawnoustrojowej tego regionu. Porady Volmara okazały się bezcenne podczas negocjacji z Francją. W związku z tym jego pozycją nie zachwiała nawet przekazana cesarzowi Ferdynandowi III wiadomość o przyjęciu przez Volmara sowitej łapówki od francuskiego szpiega ${ }^{37}$.

$\mathrm{Na}$ Volmarze nie kończyła się lista obrońców interesów cesarskich. Zarówno on, jak i hrabiowie Trauttmansdorff, Nassau-Hadamar i Lamberg oraz radca Krane korzystali z pomocy sekretarzy, który byli Peter Gözmann, Wilhelm Schröder, Matthias Geych, Egon Gail i Johann Bösendorff ${ }^{38}$. Należy dodać w tym miejscu, że dwór wiedeński wspierany był jeszcze dodatkowo przez przedstawicieli reprezentujących cesarza jako króla Czech (hrabia Ferdinand Ernst von Wallenstein i Georg von Plettenberg) i arcyksięcia Austrii (cesarscy radcy nadworni: hrabia Georg Ulrich von Wolkenstein i doktor nauk prawnych Leonhard Richtersberger). Mógł również liczyć na poparcie Johanna von Giffen, delegata młodszego brata Ferdynanda III, arcyksięcia Leopolda Wilhelma. Ten ostatni skomasował w swym ręku kilka głosów, ponieważ był nie tylko wielkim mistrzem ocalałych po sekularyzacji pruskiej z 1525 r. resztek Zakonu Krzyżackiego, ale również biskupem Pasawy, Strasburga i Halberstadt oraz księciem-opatem Murbach ${ }^{39}$.

Najsłabszy zespół negocjatorów spośród wszystkich mocarstw posiadała Hiszpania. Przez pierwsze dwa lata obrad liderem delegacji był Diego de Saavedra Fajardo, który przybył do Münster 6 XI 1643 r. Po szybkiej utracie bliskiego współpracownika (Lope Zapata de Valtierra, hrabia de Walter zmarł 2 IV 1644 r. w Münster) mógł liczyć na pomoc tylko dwóch osób. Byli nimi: członek Rady Brabancji, reprezentant okręgu burgundzkiego (tj. hiszpańskich posiadłości w Cesarstwie), licencjat prawa Jean Cuyermans oraz prokurator generalny parlamentu w Dole, członek Rady Flandrii, doktor nauk prawnych Antoine Brun. Dopiero w 1645 r. dokooptowano do nich biskupa 's-Hertogenbosch, doktora teologii Josepha de Bergaigne. Najwybitniejszą osobowością w tym gronie był Saavedra, pisarz polityczny i myśliciel, który po zdobyciu wykształcenia prawniczego na uniwersytecie w Salamance rozpoczął w 1612 r. pracę w hiszpańskiej dyplomacji. Był przez wiele lat sekretarzem ambasady Hiszpanii w Rzymie, później zaś ambasadorem w Państwie Kościelnym (1631), Bawarii (1633), na sejmie Rzeszy w Ratyzbonie (1636), w Mantui (1638) i Szwajcarii (1638-1642). Spore doświadczenie dyplomatyczne posiadał oprócz niego tylko Bergaigne, który w 1636 r. działał z powodzeniem w Ratyzbonie jako negocjator przy elekcji Ferdynanda III na króla rzymskiego (niemieckiego), w latach 1639 i 1643-1644 podejmował zaś z ramienia Hiszpanii pertraktacje z Holandią

${ }^{37}$ M. B r a u b a c h, Der Westfälische Friede, s. 22-24; F. D i c k m a n n, Der Westfälische Frieden, s. 195-196; H. v on und zu Egloff ste i n, Volmar Isaak, w: ADB XL (1896), s. 263-269; R. F u k a 1 a, Dramat Europy. Wojna trzydziestoletnia (1618-1648) a kraje Korony Czeskiej, Wrocław 2015, s. 384; M. H e n g e r e r, Kaiser Ferdinand III. (1608-1657). Eine Biographie, Wien-Köln 2012, s. 240-242; K. R e p g e n, Dreißigjähriger Krieg, s. 653-655;

S. We s t p h a l, Der Westfälische Frieden, s. 45-46.

${ }^{38}$ APW, seria III, dział D: Varia, t. I, s. 345.

39 Tamże, s. 348-351; F. B o s b a c h, Die Kosten, s. 16. 
w sprawie traktatu pokojowego ${ }^{40}$. Słabość poselstwa hiszpańskiego pogłębił jej nowy przewodniczący Gaspar de Bracamonte y Guzmán, hrabia de Peñaranda, który pojawił się w Münster 5 VII 1645 r. Peñaranda był protegowanym wszechwładnego pierwszego ministra króla Filipa IV, księcia Olivaresa i z racji swego zatrudnienia w administracji finansowej nie był przygotowany do nowej roli. Pracę dyplomaty utrudniała mu ponadto słaba znajomość języka francuskiego oraz ciągłe choroby spowodowane wilgotnym westfalskim klimatem. Na domiar złego nie układała się najlepiej współpraca Peñarandy z Saavedrą. Odwołanie Saavedry i jego wyjazd z Münster (9 IV 1646) przyniosły odwrotny skutek do zamierzonego. Doszło do jeszcze większego odosobnienia Peñarandy, tym bardziej że utracił on nieco później drugiego z dyplomatów, Bergaigne’a, który zmarł 24 X 1647 r. w Münster. Największym problemem delegacji hiszpańskiej był jednak fakt, że żaden z jej członków faktycznie nie negocjował. Hiszpanie ograniczali się bowiem do przedkładania życzeń swojego rządu, które w momencie dotarcia poczty z Madrytu do Westfalii były niejednokrotnie zdezaktualizowane przez wydarzenia wojenne ${ }^{41}$.

Monolitem nie była również delegacja szwedzka, choć w jej składzie znaleźli się dyplomaci i politycy tej miary, co hrabia Södermöre, Johan Oxenstierna, kanclerz nadworny, baron Johan Adler Salvius, baron Alexander Erskein, baron Schering Rosenhane i profesor elokwencji na uniwersytecie w Uppsali Mathias Biörenclou. Przysłużył się do tego sternik szwedzkiej nawy państwowej, kanclerz Axel Oxenstierna, który nie chcąc wracać do Niemiec, powierzył stanowisko głównego posła swemu synowi Johanowi. Młody Oxenstierna nie cieszył się sympatią pozostałych członków poselstwa szwedzkiego. Był człowiekiem aroganckim, szorstkim i nieprzyjemnym w obyciu, nastawionym na to, aby utwierdzić autorytet Szwecji i zdyskontować za wszelką cenę wieloletnie, kosztowne zaangażowanie swego państwa w Niemczech. Obecność Oxenstierny nie była w smak starszemu od niego o 21 lat Salviusowi, który reprezentował Szwecję w Cesarstwie od powrotu kanclerza do Sztokholmu w 1636 r. Należał on do najwybitniejszych i najlepiej wykształconych dyplomatów tamtych czasów. W 1619 r. uzyskał stopień doktora nauk prawnych, a studiował też filozofię i medycynę. Służbę w dyplomacji szwedzkiej rozpoczął w $1622 \mathrm{r}$. Odznaczył się w misjach dyplomatycznych do Elektoratu Saksonii (1622), Danii (1623) i północnych Niemiec (1624). W 1625 r. towarzyszył królowi Gustawowi II Adolfowi w kampanii inflanckiej i uczestniczył w pertraktacjach z pełnomocnikami polskiego władcy Zygmunta III Wazy w Szadowie. Brał też udział w rokowaniach pokojowych w Lubece (1629), później zaś, w latach 1630-1634, sprawował

${ }^{40}$ APW, seria III, dział D: Varia, t. I, s. 345-346; D. S a a v e d r a F a j a r d o, Empresas políticas, wyd. F. J. Díez de Revenga, Barcelona 1988, s. XII-XVI; T. A 1 b e r d ing k, Bergaigne Joseph von, w: ADB II (1875), s. 366; S. B o a d a s C a b ar roc a s, Camino a la Paz: el viaje de Saavedra Fajardo a Münster, w: Del verbo al espejo. Reflejos y mirandas de la literatura hispánica, Barcelona 2011, s. 67-68, 75-76.

${ }^{41}$ M. B r a u b a c h, Der Westfälische Friede, s. 11, 35-37; F. D i c k m a n n, Der Westfälische Frieden, s. 194, 198; M. R o h r s c h n e i d e r, Terrible es este Congreso: Wahrnehmungen der Fremde und Verhandlungsdispositionen im Spiegel der Berichte der spanischen Gesandten auf dem Westfälischen Friedenskongress, w: Wahrnehmungen des Fremden. Differenzerfahrungen von Diplomaten im 16. und 17. Jahrhundert, Münster 2007, s. 245-264; S. W e s t p h a 1, Der Westfälische Frieden, s. 45. 
w Hamburgu funkcję generalnego komisarza wojennego w Niemczech. W marcu 1638 i w czerwcu 1641 r. zawierał w imieniu Szwecji układy z Francją, a następnie położył podwaliny pod pokój europejski. Przyczynił się mianowicie 25 XII $1641 \mathrm{r}$. do podpisania w Hamburgu porozumienia między Szwecją, Francją a cesarzem, które przewidywało zwołanie międzynarodowego kongresu pokojowego w Münster i Osnabrück. Doświadczenie polityczne nabyte w Niemczech podpowiadało Salviusowi, że pokój może być osiągnięty tylko przez rozwiązania kompromisowe. Z tych też względów utrzymywał prywatną korespondencję z królową szwedzką Krystyną, która miała zbliżone do niego poglądy i propagowała kurs pojednawczy w Paryżu za pośrednictwem wybitnego teoretyka prawa międzynarodowego Hugona Grotiusa jako swojego prywatnego agenta ${ }^{42}$.

Dyplomaci szwedzcy wyróżniali się także pod względem pochodzenia społecznego. Schering Rosenhane, podobnie jak Oxenstierna, wywodził się z rodziny arystokratycznej, piastującej od wielu pokoleń wysokie urzędy państwowe. Pozostali członkowie delegacji legitymowali się jednak szlachectwem świeżo nabytym za zasługi i brali swój rodowód z niższych stanów. Mathias Biörenclou był synem młynarza z Nykvarn w Sudermanii, Salvius zaś - synem pisarza miejskiego z Strängnäs. Świetnym pochodzeniem nie mógł poszczycić się również Alexander Erskein, syn kupca z zachodniopomorskiej Gryfii. Był on potomkiem szkockich emigrantów, ale sam identyfikował się ze Szwecją. Miał za sobą długi staż pracy w szwedzkiej administracji wojskowej i służbie dyplomatycznej. Sprawował funkcję szwedzkiego agenta w zachodniopomorskim Strzałowie (1628-1631), rezydenta w Erfurcie (16321634), radcy-asystenta i radcy wojennego na Pomorzu Przednim (1638-1640), później zaś na całym Pomorzu Zachodnim (od 1640 r.). W 1643 r. objął stanowisko prezydenta Sądu Nadwornego dla Pomorza Przedniego. Pełnił liczne misje dyplomatyczne. Uczestniczył w rokowaniach, które zakończyły się 14 VII $1641 \mathrm{r}$. zawarciem zawieszenia broni z elektorem brandenburskim Fryderykiem Wilhelmem. Wyróżnił się również podczas prowadzonych latem 1645 r. negocjacji z księciem siedmiogrodzkim Jerzym I Rakoczym ${ }^{43}$.

Poselstwo francuskie liczyło początkowo sześć osób. W jego składzie znaleźli się Claude de Mesmes hrabia d'Avaux, Abel Servien hrabia de la Roche des Aubiers,

${ }^{42}$ APW, seria III, dział D: Varia, t. I, s. 346-347; B. B o ëth i u s, Johan Adler Salvius, w: Svenskt biografiskt lexikon, t. I, Stockholm 1918, s. 143-156; M. B r a u b a c h, Der Westfälische Friede, s. 33-35; A. C z w o ł e k, Konflikt Lwa Sapiehy, wojewody wileńskiego i Krzysztofa Radziwiłła, hetmana polnego litewskiego na tle problemów militarnych i politycznych Rzeczypospolitej w latach 1625-1633, Czasy Nowożytne 15, 2003, s. 109-110; F. D i c k m a n n, Der Westfälische Frieden, s. 197-198; H. D r o s t e, Ein Diplomat zwischen Familieninteressen und Königsdienst. Johan Adler Salvius in Hamburg (1630-1650), w: Nähe in der Ferne. Personale Verflechtung in den Außenbeziehungen der Frühen Neuzeit, Berlin 2005, s. 87-104; S. L u ndkvist, Die schwedischen Friedenskonzeptionen und ihre Umsetzung in Osnabrück, w: Der Westfälische Friede (jak w przyp. 3), s. 349-359; S. W e s t p h a 1, Der Westfälische Frieden, s. 45, 48.

${ }^{43}$ B. B o ët h i u s, Johan Adler Salvius, s. 143-144; H. D r o s t e, Im Dienst der Krone. Schwedische Diplomaten im 17. Jahrhundert, Berlin 2006, s. 390-391; B. H i l d e b r a n d, Alexander Erskein, w: Svenskt biografiskt lexikon, t. XIV (1953), s. 462-464; G. W i t t r o c k, Mattias Biörenklou, w: tamże, t. IV (1924), s. 465-466. 
Melchior de Harod de Senevas markiz de Saint-Romain, były ambasador Francji w Polsce Claude de Salles baron de Rorté (zastąpiony w 1645 r. przez Jeana de la Barde barona de Marolles-sur-Seine) oraz dwaj sekretarze: pan de Préfontaine i Jean Coiffier ${ }^{44}$. Tarcia wśród Francuzów wynikały bardziej z personalnych animozji aniżeli różnic politycznych. Dwaj liderzy, hrabia d'Avaux i Abel Servien, przybyli na rokowania do Münster odpowiednio 18 III i 5 IV $1644 \mathrm{r}^{45}$, zaliczali się do grona szlachty administracyjnej. Większe doświadczenie w pracy zagranicznej posiadał d'Avaux. Dał się wcześniej poznać z jak najlepszej strony, wypełniając w latach 1627-1632 misje dyplomatyczne we Włoszech (Wenecja, Mantua, Florencja, Turyn, Rzym), negocjując rozejm polsko-szwedzki w Sztumskiej Wsi w 1635 oraz układ francusko-szwedzki w Hamburgu w 1638 r. Brał również udział w rokowaniach z delegatami Szwecji i cesarza, które zakończyły się 25 XII 1641 r. zawarciem układu hamburskiego i zapowiedzią zorganizowania kongresu pokojowego kończącego wojnę trzydziestoletnią. Servien miał na swoim koncie tylko dwa duże sukcesy dyplomatyczne. W 1628 r. doprowadził do wyznaczenia granicy z Hiszpanią, później zaś jako ambasador nadzwyczajny w Sabaudii wynegocjował 6 IV $1631 \mathrm{r}$. korzystny dla Francji traktat pokojowy w Cherasco ${ }^{46}$. Bardziej zamożny i pewny siebie d'Avaux dążył do zmarginalizowania Serviena. Ten jednak dysponował poparciem pierwszego ministra Francji, kardynała Mazariniego, więc nie zamierzał podporządkować się koledze. Servien chciał ugrać dla Francji maksymalne korzyści, podczas gdy d'Avaux reprezentował stanowisko bardziej ustępliwe i elastyczne. Obaj wszakże nie życzyli sobie, aby Francja była kojarzona z koncesjami na rzecz protestantów. Różnice zdań między dwójką dyplomatów postanowiono w końcu ukrócić. Powołano w tym celu na stanowisko przywódcy poselstwa Henryka II Orleańskiego, księcia de Longueville, który pojawił się w Münster 30 VI 1645 r. Rok później skład poselstwa francuskiego uzupełnił jeszcze Henri Groulart pan de La Court ${ }^{47}$.

Najmniej można powiedzieć na temat edukacji francuskich dyplomatów. Wydaje się, że najlepiej wykształconym przedstawicielem tej delegacji był Servien, który pobierał nauki w szkole Notre Dame w Grenoble (1604-1606), później zaś w Wiedniu i na uniwersytecie w Valence. Ukoronowaniem edukacji był stopień doktora prawa uzyskany na uniwersytecie w Orleanie ${ }^{48}$.

Na tle pozostałych poselstw wyróżniał się liczny, ośmioosobowy zespół negocjatorów holenderskich, którym przydano jeszcze do pomocy sekretarza Jacoba van der Burgh. Liczba posłów wynikała z konfederacyjnego charakteru państwa, składającego

${ }^{44}$ APW, seria III, dział D: Varia, t. I, s. 346; A. T i s c h e r, Französische Diplomatie, s. $157-171$.

${ }^{45}$ APW, seria II, dział B: Die französischen Korrespondenzen, t. I, opr. U. Irsigler, K. Goronza, Münster 1979, s. LV-LVI.

${ }^{46}$ G. B ra u n, La connaissance du Saint-Empire en France du baroque aux Lumières 1643-1756, München 2010, s. 129-131; A. T i s c h e r, Französische Diplomatie, s. 105-126.

${ }^{47}$ M. B r a u b a ch, Der Westfälische Friede, s. 28-31; G. B r a u n, La connaissance, s. 136-137; F. D i c k m a n n, Der Westfälische Frieden, s. 196-197; A. T i s c h e r, Französische Diplomatie, s. 127-157, 163-166, 171-180; S. We s t p h a 1, Der Westfälische Frieden, s. 48; P. H. W i 1 s o n, Wojna trzydziestoletnia, s. 651.

${ }^{48}$ H. D u c c i n i, Guerre et paix dans la France du Grand Siècle. Abel Servien, diplomate et serviteur de l'État (1593-1659), Seyssel 2012, s. 23-24. 
się z siedmiu prowincji. Przewodniczącym delegacji i jej rzecznikiem był Barthold van Gent, reprezentujący Geldrię. Wspomagali go solidarnie przedstawiciele Holandii i Fryzji: Johan van Mathenesse, Adriaan Pauw i Frans van Donia oraz wysłannicy Overijssel i Groningen: Willem Ripperda i Adriaan Clant. Nad wszystkimi górował doświadczeniem i wymową faktyczny, choć nieformalny przywódca misji Adriaan Pauw, były wielki pensjonariusz Holandii (1631-1636). Pochodził on z bardzo bogatej rodziny kupieckiej i był synem ośmiokrotnego burmistrza Amsterdamu. Po zdobyciu wykształcenia prawniczego na uniwersytecie w Lejdzie dzielił swój czas pomiędzy działalność gospodarczą oraz karierę polityczną i dyplomatyczną. Zasłynął jako negocjator sojuszu zaczepno-obronnego z Francją zawartego w Paryżu w 1635 r. $\mathrm{Na}$ kongresie westfalskim opowiadał się za pokojem i kompromisem z Hiszpanią. Przeciwnego zdania był jednak reprezentant Utrechtu Godard van Reede, pan na Nederhorst, znany wcześniej z aktywnej działalności w orańskiej partii wojennej. Uchodził on bardziej za biznesmena niż polityka. Rekultywował poldery, osuszał mokradła i jeziora oraz inwestował duże kwoty w Holenderską Kompanię Zachodnioindyjską, przemysł zbrojeniowy i handel bronią ze Szwecją. Żyjąc niezbyt oszczędnie, przyjął od francuskich dyplomatów łapówkę w wysokości 100 tysięcy florenów, za co zablokować miał ratyfikację holendersko-hiszpańskiego układu pokojowego. Co więcej, przekonał do tego samego swojego kolegę, przedstawiciela Zelandii Johana de Knuyta ${ }^{49}$. Niderlandzkie przepisy ustrojowe mówiły wyraźnie o tym, że traktat pokojowy nie może wejść w życie bez wymaganej jednomyślności siedmiu prowincji. Stąd też osobiste zdanie nawet jednego członka poselstwa odgrywało tutaj kapitalne znaczenie. Holendrzy potwierdzili 30 I 1648 r. wstępny projekt układu z Hiszpanią jako pokój z Münsteru. Dwór madrycki uznał holenderską niepodległość, zgodził się zamknąć Skaldę dla handlu i zachować w rękach Holendrów podbite przez nich ziemie na południe od Renu, w tym Maastricht. Były to dla Holendrów bardzo korzystne warunki. Po ratyfikowaniu ich przez sześć z siedmiu prowincji (9 III 1648) rozpoczęły się naciski na van Reedego. Dużą presję zaczęła wywierać na niego utrechcka szlachta. W ślad za nią podążyły władze Utrechtu, które 16 IV 1648 r. oficjalną drogą nakazały swemu przedstawicielowi złożenie podpisu pod układem. Ten jednak grał na zwłokę, zasłaniając się problemami zdrowotnymi. Hiszpańscy dyplomaci obawiali się, że śmierć van Reedego opóźni znacząco ratyfikację układu. Składali unieruchomionemu w łóżku Holendrowi wizyty, licząc wciąż na zmianę jego stanowiska. W końcu dopięli swego i 30 IV 1648 r. van Reede podpisał się wreszcie pod traktatem. Umarł kilka tygodni później, 25 VI 1648 r. $^{50}$

Liczba osób przybyłych na kongres westfalski była dużo większa od podawanej oficjalnie. Wszystkim dyplomatom towarzyszył bowiem dodatkowy personel.

${ }^{49}$ APW, seria III, dział D: Varia, t. I, s. 347; H. W. J. d e B o e r, H. B r u c h, De betekenis van Adriaan Pauw voor Heemstede, w: Adriaan Pauw (1585-1653). Staatsman en ambachtsheer, Heemstede 1985, s. 13-44; M. B r a u b a c h, Der Westfälische Friede, s. 38-39; F. D i c k m a n n, Der Westfälische Frieden, s. 198; P. L. M u 11 e r, Pauw Adriaen, w: ADB XXV (1887), s. 301-302; P. H. W i 1 s o n, Wojna trzydziestoletnia, s. 704.

${ }^{50}$ D. E. A. F a b e r, R. d e B r u i n, Utrecht als Gegner des Münsteraner Friedensprozesses, w: 1648. Krieg und Frieden in Europa, t. I: Politik, Religion, Recht und Gesellschaft, München 1998, s. 413-420; J. J. P o el h e k k e, De Vrede van Munster, 's-Gravenhage 1948, s. 461$466,458-501,512-538$. 
W rekordowym towarzystwie stawili się Francuzi. Świta hrabiego d'Avaux liczyła 200 osób, a Serviena i jego żony - 119. Do tego doszedł jeszcze liczący 186 osób orszak księcia de Longueville i 14 osób w poczcie pana de La Court. W skład tych delegacji wchodzili: paziowie, gwardziści, kanceliści, służący, kucharze, piekarze, paszteciarze, cukiernicy, posłańcy zajmujący się zakupami, praczki, kapłani, medycy i chirurdzy. Nie zabrakło także koniuszych, krawców, lokajów, stajennych, woźniców i pocztylionów. Książę de Longueville zatrudniał do pracy w kuchni aż 40 osób. Wśród przybyszów francuskich wyróżniało się też otoczenie Serviena, który sprowadził dla swej żony sześć szlachetnie urodzonych dam do towarzystwa, trzy pokojówki i baletmistrza ${ }^{51}$.

Niewiele różniła się delegacja głównego posła szwedzkiego, Johana Oxenstierny, który przywiódł ze sobą 144 ludzi. Na tym tle wyjątkowo skromnie prezentowały się świty jego kolegów Salviusa (22 osoby) i Rosenhane (14 osób). Sporą rzeszę pracowników zatrudniali reprezentanci cesarza - Trauttmansdorff (100 osób), hrabia Nassau-Hadamar (72 osoby), Auersperg (9 osób) i Lamberg (27 osób). Imponujące rozmiary miały także poselstwa innych państw. Przewodniczący przedstawicielstwa hiszpańskiego, hrabia Peñaranda, pojawił się w Münster w towarzystwie 112 osób, natomiast jego kolega Saavedra - w otoczeniu 35 ludzi. Dotrzymywali im kroku Duńczycy, którzy mieli na miejscu obrad 106 osób. Z mniej licznymi pocztami stawili się Holendrzy (74 osoby), Portugalczycy (33 osoby) i delegat Katalonii (20 osób) ${ }^{52}$. Największą świtę spośród stanów Rzeszy Niemieckiej przywiódł poseł arcybiskupa-elektora Kolonii biskup Wartenberg (161 osób). Pozostali elektorzy byli bardziej oszczędni. Przykładowo poselstwo elektora saskiego liczyło wraz z obsługą 31 osób. Trzej reprezentanci elektora brandenburskiego, hrabia Sayn-Wittgenstein, Heiden i baron von Löben, przewodzili zespołom złożonym odpowiednio z 42, 13 i 9 ludzi. Heiden i Löben nie mieli własnego personelu kuchennego i byli zmuszeni korzystać w tym zakresie z pomocy swego kolegi. Nie znamy liczby osób zatrudnionych przez poselstwo arcybiskupa-elektora Moguncji. Wiemy tylko, że świta dwóch jego wysłanników, Brömsera i Krebsa, składała się z 18 osób ${ }^{53}$. Na przeciwległym biegunie znajdowały się delegacje mniej znaczących niemieckich władców terytorialnych oraz miast. Przykładowo Lampadius - poseł książąt brunszwicko-lüneburskich z Grubenhagen i Calenberg - posiadał kancelistę, 2 służących, 2 osoby obsługujące transport konny, kucharza i gońca. Z kolei przewodniczący delegacji bremeńskiej, syndyk Koch, miał do pomocy tylko 4 osoby. Poselstwo Norymbergi liczyło wraz z personelem pomocniczym 7 ludzi, Frankfurtu nad Menem - 6 ludzi, a Lubeki i Augsburga - po 5 ludzi. Jeszcze mniejszą liczbą osób towarzyszących dysponował reprezentant Szwajcarii, burmistrz Bazylei Wettstein, który przybył do Münster 28 XII 1646 r. w asyście swego syna (jako sekretarza legacji) oraz 2 służących ${ }^{54}$.

Westfalscy gospodarze mieli problem z obsługą tak wielkiej masy ludzi. Wszędzie panowała ciasnota. Dobrymi warunkami cieszyły się tylko niektóre poselstwa

${ }^{51}$ APW, seria II, dział B, t. I, s. LXIV-LXV; F. B o s b a c h, Die Kosten, s. 22-23.

${ }^{52}$ F. B o s b a ch, Die Kosten, s. 22-23; H. Lahrkamp, Dreißigjähriger Krieg, Westfälischer Frieden. Eine Darstellung der Jahre 1618-1648, Münster 1999, s. 243.

${ }^{53}$ F. B o s b a c h, Die Kosten, s. 22-24, 26.

54 Tamże, s. 24; F. G a 11 a t i, Die formelle Exemtion, s. 464. 
w Münster. Nuncjusz apostolski Chigi zamieszkał ze swoją piętnastoosobową świtą w tamtejszym klasztorze minorytów, a hiszpański hrabia Peñaranda - w nowo wybudowanym skrzydle klasztoru franciszkanów obserwantów. Wygodny dach nad głową znalazł w Münster również szwedzki dyplomata, baron Rosenhane. Rozlokował się on w przestronnym domu lekarza miejskiego, doktora Bernharda Rottendorffa $^{55}$. Oddzielne mieszkania mieli dwaj Francuzi, hrabia d'Avaux i książę de Longueville, a także mediator wenecki Contarini i poseł cesarski hrabia Nassau-Hadamar, którzy rezydowali w zabudowaniach kurii biskupiej na placu katedralnym w Münster. Duńczycy wynajmowali 6 domów oraz dodatkowo 5 kwater dla personelu, a dyplomaci Republiki Zjednoczonych Prowincji Niderlandów - dom gildii kupieckiej w Münster oraz kwatery u 13 innych właścicieli. Gorzej rzecz się miała z poselstwami niemieckich władców terytorialnych. Reprezentant arcybiskupa-elektora Moguncji, Krebs, nie mając innej alternatywy, ulokował w jednej małej izbie swojego skrybę kancelaryjnego i 2 służących. Na jeszcze większe niewygody było skazanych 29 członków poselstwa bawarskiego, którzy musieli dzielić się 18 łóżkami. Z kolei przedstawiciel Szwajcarii, z braku czegoś lepszego, zgodził się na zamieszkanie w cuchnącym kiełbasą i tranem pokoju położonym nad warsztatem tkackim ${ }^{56}$.

Liczebność poselstw uczestniczących w kongresie westfalskim nie miała większego wpływu na kształt postanowień. Większość personelu negocjatorów pochodzących z europejskich mocarstw była utrzymywana dla budowania ich prestiżu i zaspokajania potrzeb niezwiązanych z dyplomacją. Niewielkie zespoły negocjatorów posiłkowane skromnym personelem potrafiły niekiedy wskórać więcej od wielokrotnie liczniejszych przedstawicielstw. Świadczy o tym chociażby przykład działającego samotnie burmistrza Bazylei Wettsteina, który, wyzyskując różnice interesów między Francją a Habsburgami, doprowadził do potwierdzenia niepodległości Szwajcarii na arenie międzynarodowej i wyemancypowania swego kraju od Rzeszy Niemieckiej zarówno na płaszczyźnie administracyjnej, jak i sądowniczej ${ }^{57}$. Dużym sukcesem zakończyła się także misja posłów meklemburskich, doktorów prawa: tajnego radcy meklemburskiego Abrahama Keysera i członka rady miejskiej Lubeki Johanna Marquarda. Oni z kolei uzyskali dla swych książąt szczodrą rekompensatę za utracony na rzecz Szwecji Wismar i wyspę Poel. W artykule XII pokoju z Osnabrück przekazano bowiem księciu meklemburskiemu na Schwerinie Adolfowi Fryderykowi I tereny sekularyzowanych biskupstw Schwerin i Ratzeburg oraz joannicką komandorię Mirow. Jego małoletni bratanek, książę meklemburski na Güstrow Gustaw Adolf, otrzymał natomiast jako zadośćuczynienie joannicką komandorię Nemerow ${ }^{58}$.

${ }^{55}$ H. B ü c k e r, Der Nuntius Fabio Chigi (Papst Alexander VII) in Münster 1644-1649. Nach seinen Briefen, Tagebüchern und Gedichten, Westfälische Zeitschrift 108, 1959, s. 1-90; H. L a h rk a m p, Dreißigjähriger Krieg, s. 244, 249.

${ }^{56}$ F. B o s b a c h, Die Kosten, s. 114-115, 118; C. H. M a y e r, Trainingshandbuch Interkulturelle Mediation und Konfliktlösung, Münster - New York 2019, s. 81; P. H. W i 1 s o n, Wojna trzydziestoletnia, s. 649.

${ }^{57}$ APW, seria III, dział B, t. I, cz. 1, s. 128-129; T. B r a n e c k i, Powstanie i rozwój, s. 95.

${ }_{58}$ APW, seria III, dział B, t. I, cz. 1, s. 141-142; F. D i c k m a n n, Der Westfälische Frieden, s. 320-321, 384, 402; S. We s t p h a 1, Westfälische Frieden, s. 102-103. 
Analiza składu poszczególnych poselstw uczestniczących w kongresie pokojowym wykazuje jednoznacznie, że tylko większość drobnych bytów politycznych z terytorium Rzeszy Niemieckiej nie wystawiła oddzielnych reprezentacji, powierzając obronę swoich interesów osobom posiadającym większą siłę przebicia. Wszystkie państwa europejskie oraz ważniejsze niemieckie władztwa terytorialne wysłały do Westfalii najlepszych z możliwych dyplomatów i polityków. Znaczna część z nich cechowała się wysokim profesjonalizmem i piastowała najwyższe urzędy ministerialne bądź miejskie. Pod względem wykształcenia prawniczego górowały nad innymi reprezentacje miast Rzeszy Niemieckiej i państw europejskich. W tej ostatniej grupie naliczono 11 doktorów nauk prawnych i trzech profesorów prawa. Przedstawicielstwa państw europejskich dysponowały także najbardziej doświadczonymi dyplomatami. Przykładowo Hiszpan Diego de Savedra Fajardo miał za sobą 31 lat służby w dyplomacji, wysłannik cesarski hrabia Maximilian von Trauttmansdorff - 27 lat, Szwed Johan Adler Salvius - 22 lata, Wenecjanin Alvise Contarini - 20 lat, a Francuz Claude de Mesmes hrabia d'Avaux - 17 lat. Wszystkie państwa europejskie opierały się na własnych dyplomatach i nie korzystały z pomocy cudzoziemskich fachowców. Wyjątek w tym względzie uczynił jedynie polski dwór królewski, który na domiar złego nie był w stanie utrzymać w Westfalii stałego przedstawicielstwa dyplomatycznego. Bierność Rzeczypospolitej Obojga Narodów, słabość polskiej dyplomacji i jej aparatu organizacyjnego, dyletanctwo króla i jego najbliższego otoczenia oraz dawanie wiary znanemu z fałszerskich wyczynów Janikowskiemu zaważyły na kompromitującym finale całej misji i ugruntowaniu słabości Władysława IV Wazy na arenie międzynarodowej.

Innego typu problemy występowały w przypadku pozostałych poselstw, zwłaszcza w zespołach posiadających w swoim składzie więcej niż jedną wybitną indywidualność. Ścierały się tam rozmaite koncepcje polityczne, dochodziło do animozji i rywalizacji, które rzutowały na skuteczność prowadzonych pertraktacji. Cesarz oraz rządy Francji, Szwecji i Republiki Zjednoczonych Prowincji Niderlandów potrafiły jednak nad tym zapanować.

\section{BIBLIOGRAFIA}

Alberdingk T., Bergaigne Joseph von, w: Allgemeine deutsche Biographie, t. II (1875).

Andretta S., La diplomazia veneziana e la pace di Vestfalia (1643-1648), Annuario dell'Istituto storico italiano per l'età moderna e contemporanea 23/24, 1971-1972.

Baumgart P., Kurbrandenburgs Kongreßdiplomatie und ihre Ergebnisse, w: Der Westfälische Friede. Diplomatie - politische Zäsur - kulturelles Umfeld - Rezeptionsgeschichte, München 1998.

Benzoni G., Contarini Alvise, w: Dizionario Biografico degli Italiani, t. XXVIII, Roma 1983.

Boadas S., Grandes diplomáticos en el congreso de Münster: Diego de Saavedra y Josep Fontanella, w: Literatura en la Guerra de Treinta Años, Vigo 2012.

Boadas Cabarrocas S., Camino a la Paz: el viaje de Saavedra Fajardo a Münster, w: Del verbo al espejo. Reflejos y mirandas de la literatura hispánica, Barcelona 2011.

Boer H. W. J. de, Bruch H., De betekenis van Adriaan Pauw voor Heemstede, w: Adriaan Pauw (1585-1653). Staatsman en ambachtsheer, Heemstede 1985.

Boëthius B., Johan Adler Salvius, w: Svenskt biografiskt lexikon, t. I, Stockholm 1918.

Bosbach F., Die Kosten des Westfälischen Friedenskongresses. Eine strukturgeschichtliche Untersuchung, Münster 1984. 
Branecki T., Powstanie i rozwój Konfederacji Szwajcarskiej w latach 1291-1515, Studia Iuridica Lublinensia 19, 2013.

Braubach M., Der Westfälische Friede, Münster 1948.

Braun G., La connaissance du Saint-Empire en France du baroque aux Lumières 1643-1756, München 2010.

Bregnsbo M., Denmark and the Westphalian Peace, w: Der Westfälische Friede. Diplomatie - politische Zäsur - kulturelles Umfeld - Rezeptionsgeschichte, München 1998.

Bücker H., Der Nuntius Fabio Chigi (Papst Alexander VII) in Münster 1644-1649. Nach seinen Briefen, Tagebüchern und Gedichten, Westfälische Zeitschrift 108, 1959.

Cardim P., „Portuguese Rebels” at Münster. The diplomatic self-fashioning in mid-17th century European politics, w: Der Westfälische Friede. Diplomatie - politische Zäsur - kulturelles Umfeld - Rezeptionsgeschichte, München 1998.

Castronovo V., Bellezia Giovanni Francesco, w: Dizionario Biografico degli Italiani, t. VII, Roma 1965.

Costa J., Quintana A., Serra E., El viatge a Münster dels germans Josep i Francesc Fontanella per a tractar les paus de Catalunya, w: Polyglotte Romania. Homenatge a Tilbert Dídac Stegmann, t. I, Frankfurt am Main 1991.

Czwołek A., Konflikt Lwa Sapiehy, wojewody wileńskiego i Krzysztofa Radziwiłła, hetmana polnego litewskiego na tle problemów militarnych i politycznych Rzeczypospolitej w latach 1625-1633, Czasy Nowożytne 15, 2003.

Demandt K. E., Geschichte des Landes Hessen, Kassel 1959.

Dickmann F., Der Westfälische Frieden, Münster 1972.

Dietrich R., Jacobus Lampadius. Seine Bedeutung für die deutsche Verfassungsgeschichte und Staatstheorie, w: Forschungen zu Staat und Verfassung. Festgabe für Fritz Hartung, Berlin 1958.

Droste H., Ein Diplomat zwischen Familieninteressen und Königsdienst. Johan Adler Salvius in Hamburg (1630-1650), w: Nähe in der Ferne. Personale Verflechtung in den Außenbeziehungen der Frühen Neuzeit, Berlin 2005.

Droste H., Im Dienst der Krone. Schwedische Diplomaten im 17. Jahrhundert, Berlin 2006.

Duccini H., Guerre et paix dans la France du Grand Siècle. Abel Servien, diplomate et serviteur de l'État (1593-1659), Seyssel 2012.

Egloffstein von und zu H., Trauttmansdorff Maximilian Graf von, w: Allgemeine deutsche Biographie, t. XXXVIII (1894).

Egloffstein von und zu H., Volmar Isaak, w: Allgemeine deutsche Biographie, t. XL (1896).

Endres R., Die Friedensziele der Ritterschaft, w: Der Westfälische Friede. Diplomatie - politische Zäsur - kulturelles Umfeld - Rezeptionsgeschichte, München 1998.

Ennen L., Ferdinand Erzbischof und Kurfürst von Köln, w: Allgemeine deutsche Biographie, t. VI, Leipzig 1877.

Faber D. E. A., Bruin de R., Utrecht als Gegner des Münsteraner Friedensprozesses, w: 1648. Krieg und Frieden in Europa, t. I: Politik, Religion, Recht und Gesellschaft, München 1998.

Fäh F., Wettstein Johann Rudolf, w: Allgemeine deutsche Biographie, t. XLII (1897).

Fukala R., Dramat Europy. Wojna trzydziestoletnia (1618-1648) a kraje Korony Czeskiej, Wrocław 2015.

Gallati F., Die formelle Exemtion der Schweiz vom Deutschen Reich im Westfälischen Frieden, Zeitschrift für Schweizerische Geschichte 28, 1948.

Gauss J., Stoecklin A., Bürgermeister Wettstein. Der Mann, das Werk, die Zeit, Basel 1953.

Hengerer M., Kaiser Ferdinand III. (1608-1657). Eine Biographie, Wien-Köln 2012.

Hildebrand B., Alexander Erskein, w: Svenskt biografiskt lexikon, t. XIV, Stockholm 1953.

Honselmann W., Peter Buschmann, Kanzler in Paderborn und Köln (1604-1673), Westfälische Zeitschrift 120, 1970.

Jugler J. F., Beyträge zur juristischen Biographie oder genauere litterarische und critische Nachrichten von dem Leben und Schriften, t. VI, Leipzig 1780. 
Kármán G., Rákóczi I., György korai kapcsolatai a Radziwiłł családdal, Acta Academiae Agriensis, Sectio Historiae 44, 2017.

L[iliencron], von R., Griesheim Heinrich Christoph von, w: Allgemeine deutsche Biographie, t. IX (1879).

Lahrkamp H., Dreißigjähriger Krieg, Westfälischer Frieden. Eine Darstellung der Jahre 16181648, Münster 1999.

Lorenz G., Die dänische Friedensvermittlung beim Westfälischen Friedenskongreß, w: Forschungen und Quellen zur Geschichte des Dreißigjährigen Krieges, Münster 1981.

Lundkvist S., Die schwedischen Friedenskonzeptionen und ihre Umsetzung in Osnabrück, w: Der Westfälische Friede. Diplomatie - politische Zäsur - kulturelles Umfeld - Rezeptionsgeschichte, München 1998.

Mayer C. H., Trainingshandbuch Interkulturelle Mediation und Konfliktlösung, Münster New York 2019.

Merlotti A., Saint Maurice, Claude Jêrome Chabod marchese di, w: Dizionario Biografico degli Italiani, t. LXXXIX, Roma 2017.

Muller P. L., Pauw Adriaen, w: Allgemeine deutsche Biographie, t. XXV (1887).

Neuhaus H., Das Reich in der frühen Neuzeit, München 1997 (Enzyklöpedie deutsche Geschichte 42).

Poelhekke J. J., De Vrede van Munster, 's-Gravenhage 1948.

Postel R., Zur „,erhaltung dern commercien und darüber habende privilegia”. Hansische Politik auf dem Westfälischen Friedenskongreß, w: Der Westfälische Friede. Diplomatie - politische Zäsur - kulturelles Umfeld - Rezeptionsgeschichte, München 1998.

Prestage E., A embaixada do Dr. Francisco de Andrade Leitão à Holanda (1642-1644), Porto 1923.

Pribram A. F., Franz Paul Freiherr von Lisola (1613-1674) und die Politik seiner Zeit, Leipzig 1894.

Repgen K., Dreißigjähriger Krieg und Westfälische Friede. Studien und Quellen, PaderbornMünchen-Wien 1998.

Rohrschneider M., Terrible es este Congreso: Wahrnehmungen der Fremde und Verhandlungsdispositionen im Spiegel der Berichte der spanischen Gesandten auf dem Westfälischen Friedenskongress, w: Wahrnehmungen des Fremden. Differenzerfahrungen von Diplomaten im 16. und 17. Jahrhundert, Münster 2007.

Rumiński J., Janikowski Krzysztof Stanisław, w: Polski słownik biograficzny, t. X, Wrocław 1962-1964.

Sánchez-Marcos F., The future of Catalonia. A sujet brûlant at the Münster Negotiations, w: Der Westfälische Friede. Diplomatie - politische Zäsur - kulturelles Umfeld - Rezeptionsgeschichte, München 1998.

Saring H., Matthias von Krockow, Baltische Studien, Neue Folge 42, 1940.

Setton K. M., Venice, Austria, and the Turks in the Seventeenth Century, Philadelphia 1991.

Steiger H., Der Westfälische Frieden - Grundgesetz für Europa? w: Der Westfälische Friede. Diplomatie - politische Zäsur - kulturelles Umfeld - Rezeptionsgeschichte, München 1998.

Stramberg von Ch., Ehrenbreitstein, Feste und Thal, w: Denkwürdiger und nützlicher rheinischer Antiquarius, welcher die wichtigsten und angenehmsten geographischen, historischen und politischen Merkwürdigkeiten des ganzen Rheinstroms. Mittelrhein: dział II, t. I, Coblenz 1845.

Strohm C., Calvinismus und Recht. Weltanschaulich - konfessionelle Aspekte im Werk reformierter Juristen in der Frühen Neuzeit, Tübingen 2008.

Teske G., Verhandlungen zum Westfälischen Frieden außerhalb der Kongreßstädte Münster und Osnabrück, Westfälische Zeitschrift 147, 1997.

Tischer A., Französische Diplomatie und Diplomaten auf dem Westfälischen Friedenskongress. Außenpolitik unter Richelieu und Mazarin, Münster 1999.

Vitale V., Diplomatici e consoli della Repubblica di Genova, Atti della Società Ligure di Storia Patria 63, 1934. 
Volk P., Adami Adam, w: Neue deutsche Biographie, t. I (1953).

Wachowiak B., przy współudziale Kamieńskiego A., Dzieje Brandenburgii-Prus u progu czasów nowożytnych (1500-1701), Poznań 2001.

Westphal S., Der Westfälische Frieden, München 2015.

Wilson P. H., Wojna trzydziestoletnia 1618-1648. Tragedia Europy, tłum. M. Kapałczyński, Oświęcim 2017.

Wisner H., Dyplomacja polska w latach 1572-1648, w: Historia dyplomacji polskiej, t. II, Warszawa 1982.

Wittrock G., Mattias Biörenklou, Svenskt biografiskt lexikon, t. IV, Stockholm 1924.

Zanon Dal Bo A., Alvise Contarini, mediatore per la Repubblica di Venezia nel congresso di Vestfalia (1643-1648), Lugano 1971.

\section{Constitution, qualifications and membership of delegations participating in the Congress of Westphalia}

\section{Summary}

There were 194 official diplomatic delegations participating in the Peace Congress of Westphalia. 178 of them came from the German Reich, the remaining ones from 16 European states. Only a small part of insignificant political entities of the German Reich resigned from sending a separate representation, relying on persons with greater power to take care of their interests. All the European states and more important German territorial rulers sent to Westphalia the best possible diplomats and politicians. A great majority of them were highly professional and held the highest ministerial or municipal offices. The representations of the cities of the Reich and European states had the best legal education. In that last group there were 11 doctors of law and 3 professors of law. Representatives of European states also had the best diplomats at their disposal. For example, Diego de Saavedra Fajardo from Spain had the experience of 31 years in diplomatic service, the imperial delegate Count Maximilian von Trauttmansdorff -27 years, the Swede Johan Adler Salvius - 22 years, Alvise Contarini from Venice - 20 years, and the Frenchman Claude de Mesmes hrabia d'Avaux - 17 years. The delegations of European states were also much more numerous than those of other participants of the Congress of Westphalia. The most numerous personnel accompanied the French diplomats. The entourages of Count d'Avaux, Duke de Longueville (Henry II of Orleans) and Abel Servien included respectively 200, 186 and 119 people. The entourage of the chief Swedish delegate Johan Oxenstierna was not much smaller, as he brought with him 144 people. At the other end of the spectrum was the representative of Switzerland, Johann Rudolf Wettstein, who came to Westphalia with his son and two servants. 